\title{
STABILITAS STATIS DAN DINAMIS KAPAL PURSE SEINE DI PELABUHAN PERIKANAN PANTAI LAMPULO KOTA BANDA ACEH NANGGROE ACEH DARUSSALAM
}

\section{Static and Dynamic Stability of a Purse seiner at Coastal Fishing Port in Lampulo Banda Aceh Nanggroe Aceh Darussalam}

\author{
Oleh:

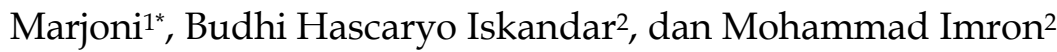 \\ ${ }^{1}$ Jurusan Teknologi Perikanan Tangkap, SUPM Negeri Ladong, Jl. Laksamana Malahayati KM. 27 Ladong-Aceh Besar. \\ 2 Departemen Pemanfaatan Sumber Daya Perikanan, FPIK, IPB, Jl. Lingkar Kampus, Darmaga - Bogor 16680 \\ ${ }^{*}$ Korespondensi: marjoni2000@yahoo.co.id
}

Diterima: 3 April 2009; Disetujui: 10 Februari 2010

\begin{abstract}
Study on stability of a purseiner, which is based in Lampulo, has never been carried out till now. The objective of the research is to analized quality of stability of a purseiner which is based in Lampulo Fishing Port based on its real load distributions. Stability analysis was carried out on some load distributions variations, such as: 1) Condition 1; departure (100\% fuel-0\% load) ; 2) Condition 2, 3 and 4; arrival from fishing ground (fuel remain 20\%, 25\%, 20\% and load of fish 100\%, $70 \%, 50 \%$ ) and 3) Condition 5; arrival from fishing ground (55\% fuel-100\% load). Krylov method combines with trapezoidal approximation was used for analyzing. The results show that in all load conditions, this purseseiner show a good stability with the highest $G Z$ maximum value in condition 4 ( $G Z$ max $0.63 \mathrm{~m}$ ) and the lowest is in conditon 5 ( $G Z$ mas 0.52). Comparing to the IMO recomendation on stability, all load variations above are comply with the recomendations.
\end{abstract}

Key words: five load variations, Lampulo purseseiner, static and dynamic stability

\section{ABSTRAK}

Analisis stabilitas terhadap kapal purse seine di Lampulo belum pernah dilakukan. Tujuan dari penelitian ini adalah menentukan kualitas stabilitas statis dan dinamis kapal purse seine yang berbasis di Pelabuhan Perikanan Pantai Lampulo berdasarkan kondisi distribusi muatan yang diaplikasikan oleh nelayan setempat. Perhitungan stabilitas dilakukan pada lima variasi kondisi muatan, yaitu: 1) kondisi 1; (100\% BBM - 0\% muatan) kapal berangkat; 2) kondisi 2, 3 dan 4; (BBM tersisa $20 \%, 25 \%, 20 \%$ dan muatan $100 \%, 70 \%, 50 \%$ ikan) kapal kembali dari fishing graund dan 3) kondisi 5; (55\% BBM - 100\% muatan) kapal kembali dari fishing ground. Analisis data menggunakan metode Krylov dengan pendekatan trapezoidal. Hasil penelitian menunjukkan bahwa stabilitas statis dan dinamis pada lima variasi kondisi muatan berada jauh di atas nilai rekomendasi IMO (kriteria A, B , C, D, E dan F). Stabilitas tertinggi terdapat pada kondisi muatan 4 (GZ max. 0,63), stabilitas terendah pada kondisi muatan 5 (GZ max. 0,52).

Kata kunci: lima variasi kondisi muatan, kapal purse seine, stabilitas statis dan dinamis

\section{PENDAHULUAN}

Luas perairan Aceh $56.563 \mathrm{~km}^{2}$, terdiri dari laut teritorial seluas $23.563 \mathrm{~km}^{2}$ dan perairan ZEE seluas $33.000 \mathrm{~km}^{2}$ (Husni, 2003). Pela- buhan Perikanan Pantai Lampulo Kota Banda Aceh NAD merupakan salah satu pelabuhan perikanan yang memiliki aktivitas penangkapan ikan tinggi, berbagai jenis kapal dan alat tangkap ikan terdapat di sana. 
Kapal purse seine adalah jenis kapal penangkap ikan yang mendominasi daerah tersebut. Operasi penangkapan dilakukan 3 hingga 6 hari per trip. Ikan sasaran tangkap terdapat pada perairan di atas 12 mil, sehingga dibutuhkan jangkauan area kapal yang tinggi. Kajian stabilitas untuk kapal-kapal di Pelabuhan Perikanan Pantai Lampulo belum dilakukan hingga saat ini. Disisi lain stabilitas merupakan hal yang utama pada keselamatan kapal dan awaknya.

Undang-undang No.31/2004 mewajibkan tiap orang yang akan membangun kapal harus mendapat persetujuan menteri perhubungan, dengan memperlihatkan gambar desain kapal. International Maritime Organisation (1995) adalah salah satu organisasi yang bergerak dibidang kelautan, organisasi ini telah mengeluarkan regulasi tentang keselamatan kapal dan awaknya, sudut kemiringan/Koppel GZ dijadikan sebagai acuan.

Berdasarkan uraian di atas, maka diperlukan penelitian yang dapat memberikan informasi tentang kondisi kualitas stabilitas statis dan dinamis beberapa variasi kondisi muatan kapal purse seine.

\section{METODOLOGI}

Studi kasus digunakan pada penelitian ini, analisis dilakukan secara deskriptif, numerik dan komparatif terhadap beberapa parameter kapal.

Penelitian ini menggunakan satu unit armada kapal purse seine yang dibangun di lingkungan Pelabuhan Perikanan Pantai Lampulo Kota Banda Aceh NAD. Data penelitian ini adalah hasil pengukuran langsung terhadap kapal purse seine Atadroe, yaitu berupa dimensi utama (panjang, lebar dan dalam kapal) dan ukuran lain yang diperlukan dalam perhitungan stabilitas.

Perhitungan stabilitas statis dan dinamis kapal purse seine meliputi analisis lima variasi kondisi distribusi muatan, tinggi KG dan draft pada setiap kondisi muatan berbeda, perbedaan tersebut mengakibatkan perbedaan kualitas stabilitas kapal. Perhitungan dilakukan untuk mendapatkan nilai GZ (lengan penegak). Dengan mengasumsikan kapal kedap air, hasil perhitungan parameter stabilitas ini kemudian dibandingkan dengan nilai yang direkomendasikan oleh IMO untuk melihat kesesuaiannya.

Lima variasi kondisi distribusi muatan tersebut dijelaskan sebagai berikut: 1) Kondisi 1 (Gambar 1); kapal berangkat menuju fishing ground dengan BBM penuh; 2) Kondisi 2, 3, dan 4 (Gambar 2, 3, dan 4); kapal kembali dari fishing ground dengan muatan $100 \%, 70 \%$, $50 \%$ ikan, sedangkan BBM tersisa $20 \%, 25 \%$, $20 \%$, (6 hari penangkapan) dan 3) Kondisi 5 (Gambar 5); kapal kembali dari fishing ground menuju fishing base dengan muatan 100\% ikan dalam palka, sedangkan BBM tersisa $55 \%$ selama tiga hari penangkapan.

Menurut BBPPI (2006) analisis terhadap perubahan berat BBM ditentukan dengan formula Pertamina, berat air tawar, bahan makanan dan kapasitas palka ditentukan dengan formula sebagai berikut:

\section{1) Pemakaian BBM}

\section{Pemakaian bahan bakar}

$=0,16 \times 0,8 \times H P \times J$

Keterangan:

$0,16=$ Konstanta formula pertamina

$0,8=$ Efisiensi mesin

$\mathrm{HP}=$ Kekuatan mesin

$\mathrm{J}=$ Lama pemakaian

2) Berat air tawar

Pemakaian air tawar $=20 \times Z \times(a / v)$

Keterangan:

$\mathrm{Z} \quad=$ Jumlah awak kapal

$\mathrm{a} / \mathrm{v}=$ Hari layar

3) Bahan makanan

$W e=Z \times C e \times(a / v)$

Keterangan:

$\mathrm{Z} \quad=$ Jumlah awak kapal

$\mathrm{Ce}=$ Koefisien berat kebutuhan bahan makanan

$\mathrm{a} / \mathrm{v} \quad=$ Hari layar

4) Kapasitas palka

$\mathrm{W}_{\mathrm{NL}}=C n l \times V$

Keterangan:

$\mathrm{W}_{\mathrm{NL}}=$ Berat muatan bersih $(\mathrm{kg})$

$\mathrm{Cnl}=$ Koefisien berat muatan bersih

$(\mathrm{kg})$ atau spesifik berat muatan

bersih (ikan + kepingan es)

$\mathrm{V} \quad=$ Volume muatan bersih $\left(\mathrm{m}^{3}\right)$

Perhitungan draft sesuai dengan perubahan variasi kondisi muatan dan nilai ton per centimeter immersion (TPC) pada masing-masing water line ditentukan dengan formula Istopo (1997):

Perubahan draft $=w / T P C$

Keterangan :

$\mathrm{w}($ selisih berat $)=$ berat baru - berat lama

TPC = Ton per centimeter immersion 


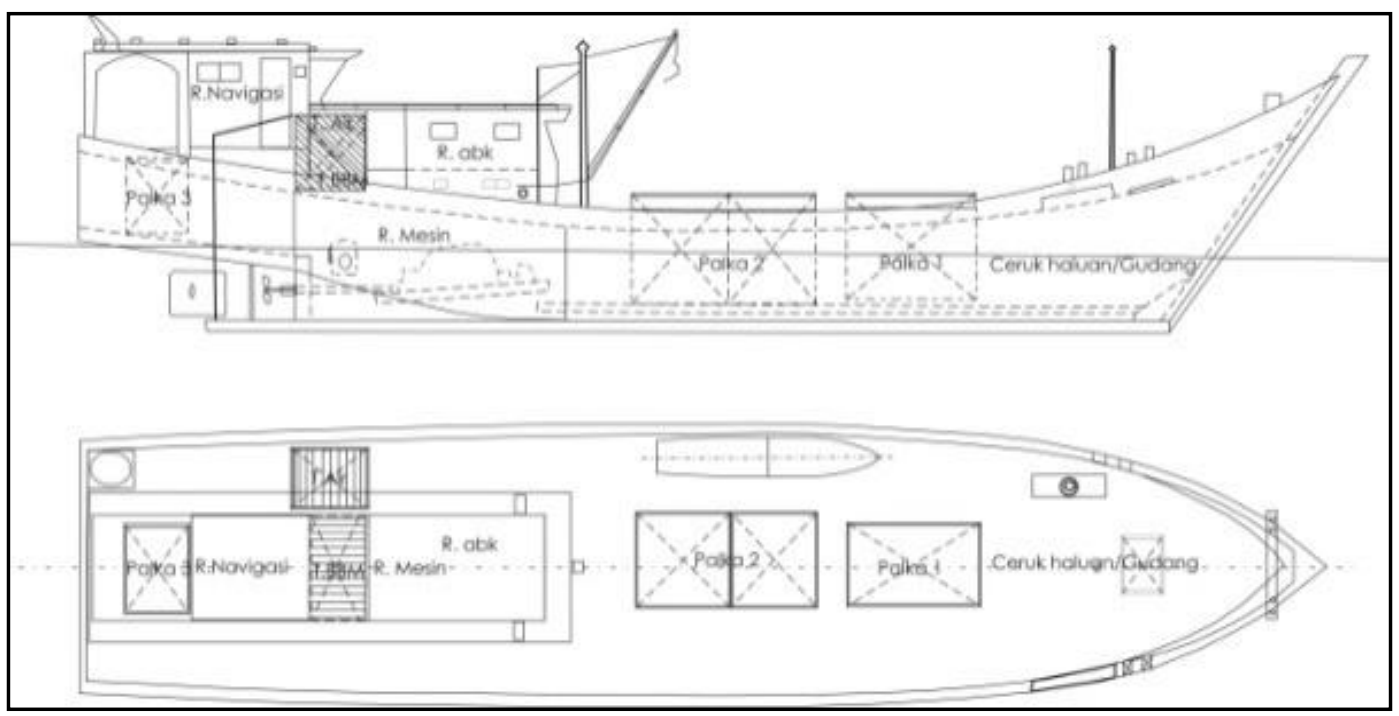

Gambar 1 Kondisi muatan 1

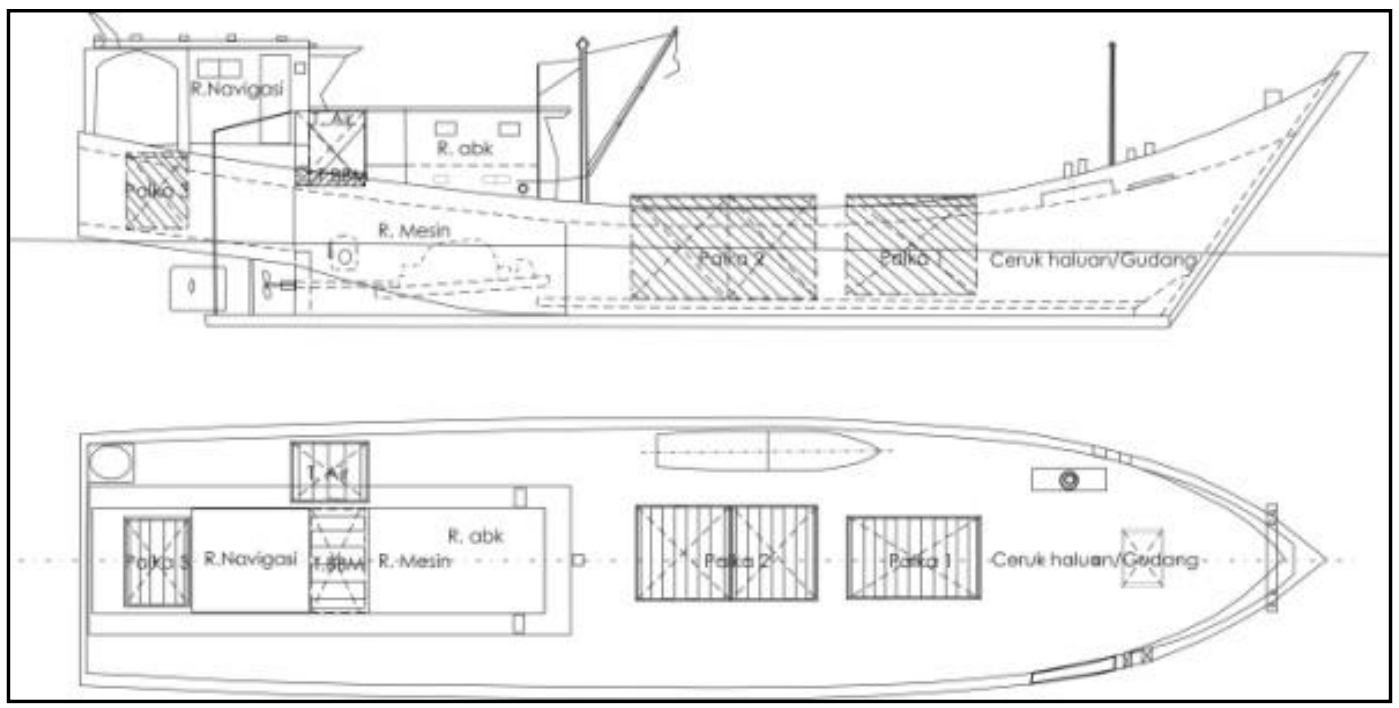

Gambar 2 Kondisi muatan 2

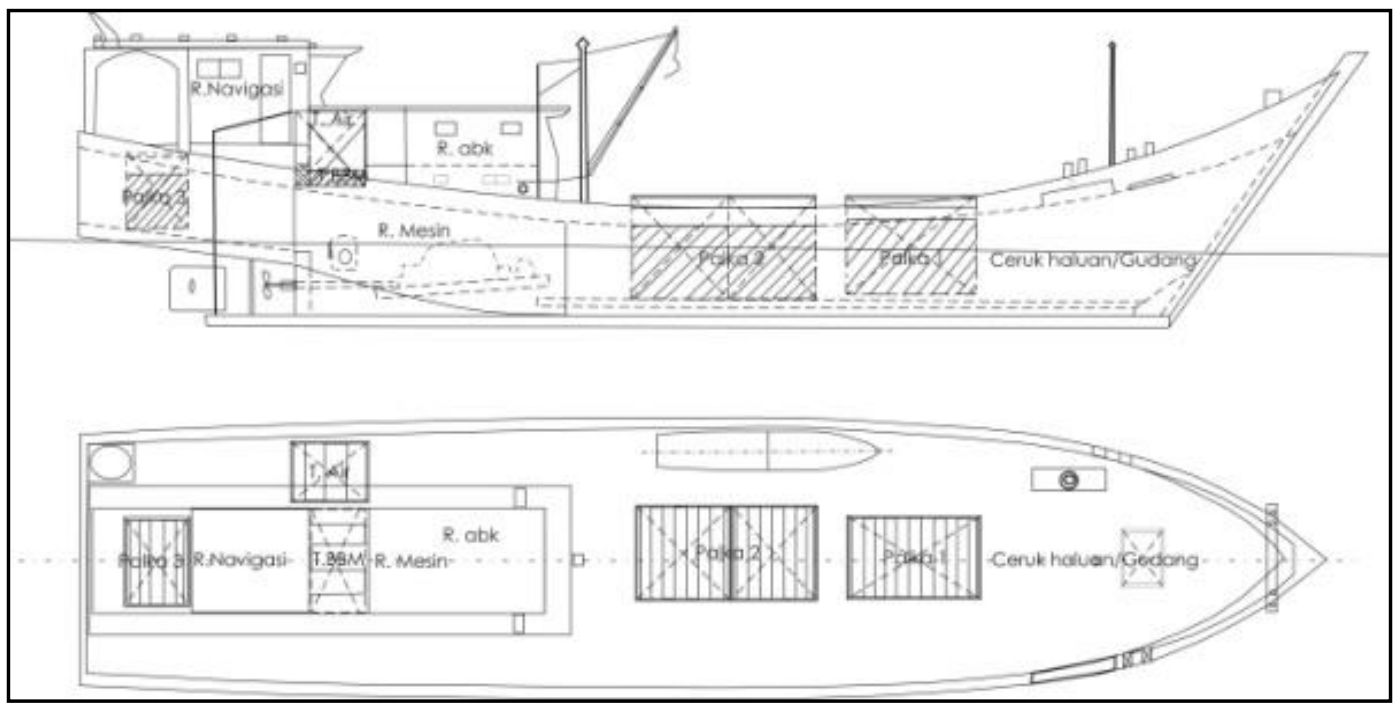

Gambar 3 Kondisi muatan 3 


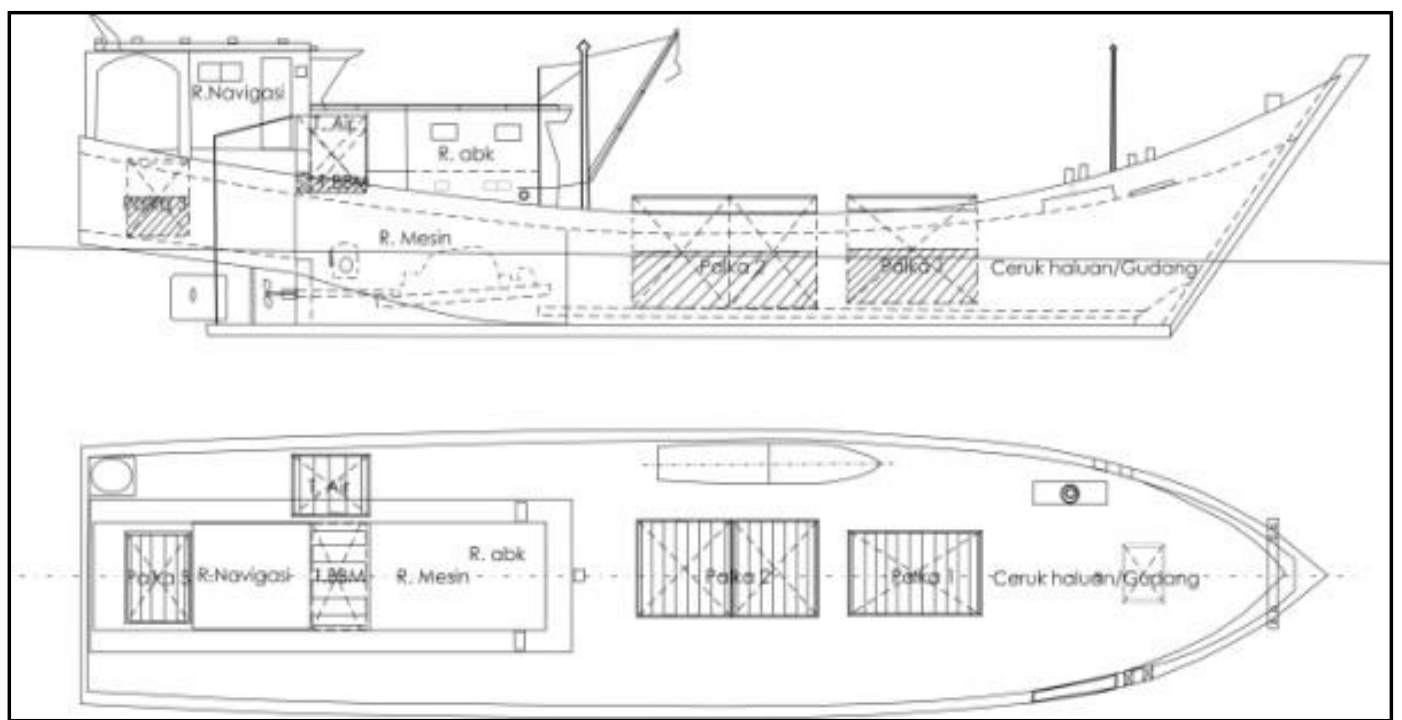

Gambar 4 Kondisi muatan 4

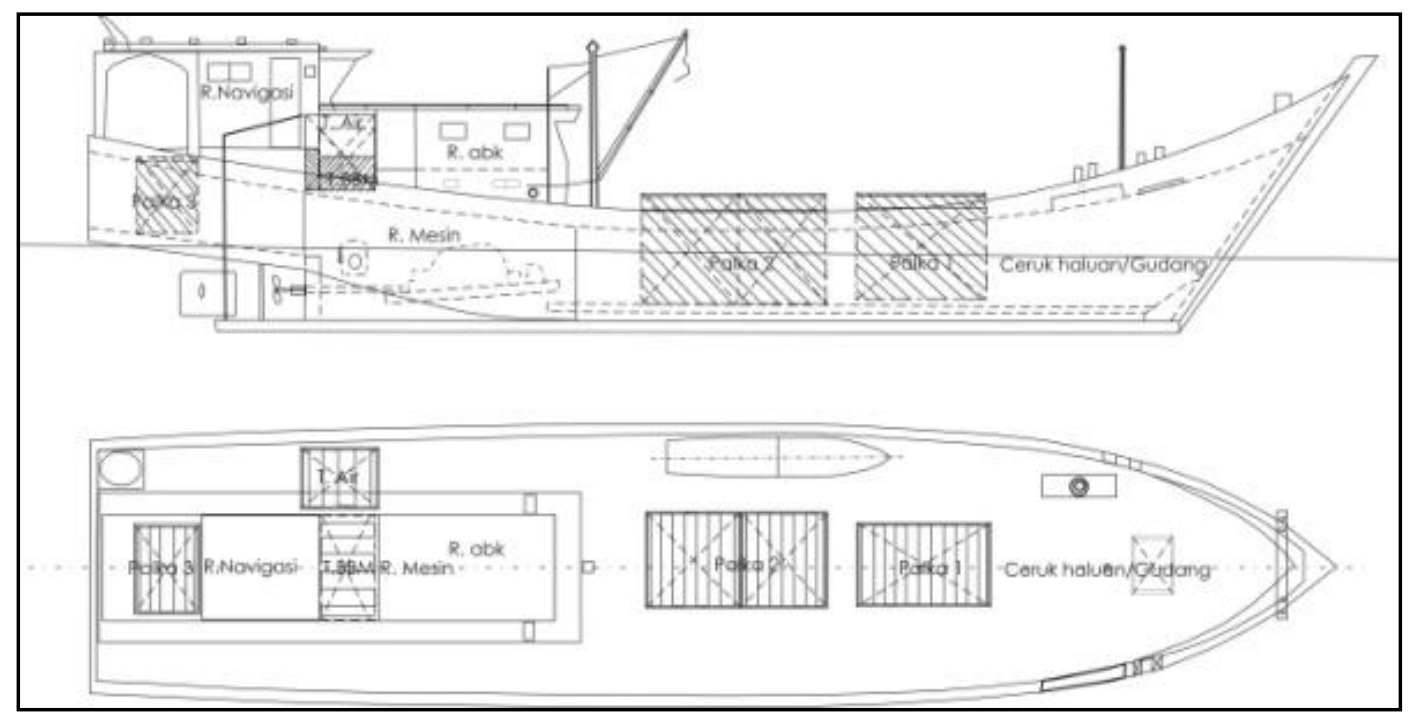

Gambar 5 Kondisi muatan 5

Analisis terhadap stabilitas statis dan dinamis dilakukan melalui kurva stabilitas statis (GZ) dengan metode Krylov dan Trapezoidal.

Perhitungan nilai GZ pada kapal Atadroe dilakukan berdasarkan sudut kemiringan pada nilai ton displacement yang berbeda. Analisis pada kondisi variasi distribusi muatan dan BBM dilakukan dengan mendapatkan nilai lengan koppel (GZ) yang diplotkan pada kurva GZ menggunakan software PGZ. Nilai GZ statis yang dihasilkan dari software PGZ, selanjutnya dilakukan perhitungan untuk mendapatkan nilai stabilitas dinamis (luas area di bawah kurva GZ), nilai yang dihasilkan dibandingkan dengan nilai yang direkomendasikan IMO.

\section{HASIL DAN PEMBAHASAN}

Waktu berangkat menuju fishing ground, distribusi muatan pada kapal purse seine ber- beda dengan waktu kembali. Waktu kapal berangkat, titik berat lebih ke belakang midship karena pusat gaya berat berada di belakang kapal akibat perbekalan dan BBM penuh. Sedangkan pada waktu kembali, titik berat akan bergerak ke depan midship karena pusat gaya berat berada dibagian depan. Hal ini disebabkan karena di bagian depan terdapat hasil tangkapan.

Tabel 1 memperlihatkan perubahan nilai titik berat kapal yang ditunjukkan oleh nilai KG seiring dengan perubahan distribusi muatan di atas kapal. Kondisi variasi 1, titik berat berada di belakang midship yang ditunjukkan oleh nilai LCG. Nilai KG pada kondisi variasi muatan 1 lebih besar dari pada kondisi variasi muatan 2 . Hal ini mengindikasikan bahwa perubahan displacement meningkatkan nilai KG dan draft, sehingga mempengaruhi nilai GZ. Derrett (1990) menjelaskan bahwa posisi titik berat (G) 
tergantung dari muatan barang dan bobot lainnya di kapal. Semua ini akan mempengaruhi stabilitas statis, karena merupakan salah satu faktor menentukan panjang lengan penegak GZ.

Kurva GZ statis dan dinamis masingmasing kondisi muatan disajikan pada Gambar 6, 7, 8, 9, dan 10. Adapun kurva GZ statis dan dinamis gabungan dari kelima kondisi muatan disajikan pada Gambar 11 dan nilai hasil perhitungan di bawah kurva stabilitas statis disajikan pada Tabel 2 dan margin (\%) Tabel 3. Hasil perhitungan terhadap stabilitas statis dan dinamis dari kelima kondisi distribusi muatan, diketahui positif. Kriteria $A, B$ dan $C$ sebagai momen penegak jauh berada di atas nilai rekomendasi IMO dan kolom margin memperlihatkan kualitas stabilitas kapal Atadroe di atas $190 \%$ lebih besar dibandingkan dengan nilai minimum kriteria IMO (Tabel 3).

Nilai GZ statis dan nilai luas area di bawah kurva $G Z$ akan berubah jika terjadi perubahan distribusi muatan. Nilai lengan $G Z$ dan jarak antara titik G ke M (GM) menjadi mengecil apabila terjadi penambahan muatan. Pada kelima kondisi variasi distribusi muatan, nilai $\mathrm{KG}$ tertinggi berada pada kondisi muatan $1(0 \%$ muatan-100\% BBM) sehingga nilai GM menjadi kecil. Akan tetapi nilai GM terendah terdapat pada kondisi muatan 5. Akan tetapi lengan $G Z$ masih jauh lebih besar dari nilai minimum yang direkomendasikan IMO. Derrett (1984) menjelaskan, jika kapal menjadi miring dan tidak dapat kembali ke posisi semula, tetapi terus bergerak ke arah kemiringan (GZ negatif), maka kapal dalam kondisi unstable equilibrium. Nilai masing-masing kurva disajikan pada Tabel 3 dan kualitas stabilitas (\%) pada Tabel 3.

Nilai GZ maksimum kelima kondisi variasi distribusi muatan berbeda satu sama lain. Nilai GZ maksimum tertinggi pada kondisi muatan $4\left(0,628\right.$ m.rad) terbentuk pada sudut $37^{\circ}$ dan $G Z$ terkecil pada kondisi muatan $5(0,525$ m.rad) terbentuk pada sudut $34^{\circ}$, ini menunjukkan kemampuan terbesar yang dimiliki kapal untuk kembali tegak setelah miring (kriteria D dan E, Tabel 2).

Vanishing angle merupakan sudut terbesar kemiringan kapal tanpa terjadinya nilai $\mathrm{GZ}$ yang negatif. Vanishing angle lima variasi kondisi muatan sama $\left(79^{\circ}\right)$, namun berbeda pada nilai stabilitas dinamis (luas area di bawah kurva statis). Besar sudut ini diketahui dari titik potong kurva $\mathrm{GZ}$ dengan sumbu X (axis), dimana nilai $\mathrm{GZ}$ statis sama dengan 0 disebut dengan angle of vanishing stability (Tabel 3). Rawson and Tupper (1989) menyatakan, selang stabilitas (range of stability), yaitu selang dimana nilai
GZ adalah positif, biasanya berada pada selang sudut $0^{\circ}$ sampai $90^{\circ}$, dimana kapal akan kembali ke posisi semula setelah momen yang menyebabkan kemiringan hilang.

Perubahan nilai ton displacement berpengaruh terhadap nilai KG, akan tetapi tidak langsung menentukan penurunan atau peningkatan nilai tersebut. Tabel 5, kondisi muatan 1 dengan bobot 39,748 ton dengan nilai $\mathrm{KG}$ 1,226 m, sedangkan kondisi muatan 2 lebih besar yaitu 44,321 ton dengan nilai KG 1,158 m. Hal ini terjadi karena kondisi 1 BBM, air tawar dan bahan makanan terkonsentrasi ditempat yang tinggi (buritan) sedangkan kondisi 2 justru sebaliknya (haluan) (Iskandar, 2007). Penempatan bobot yang tinggi secara vertikal pada kapal akan besar pengaruhnya terhadap perubahan nilai KG, demikian pula sebaliknya.

Tabel 4 menjelaskan bahwa nilai ton displacement berpengaruh terbalik terhadap tinggi metacentre (GM). Semakin besar displacement, maka tinggi metacentre menurun dan nilai KG bertambah. Hal ini disebabkan sebuah beban w (ton) meningkatkan draft, maka centre of gravity akan meningkat dan tinggi metacentre menurun. Perubahan GM tidak sebanding dengan perubahan nilai centre of grafity. Perubahan pada nilai metacentre berpengaruh terhadap periode oleng.

Periode oleng adalah sejumlah waktu yang dibutuhkan oleh kapal untuk kembali tegak setelah kapal miring karena gaya yang bekerja padanya. Periode oleng kapal Atadroe disajikan pada Tabel 5 . Kelima kondisi distribusi muatan memperlihatkan nilai periode oleng 3,0-3,2 detik, nilai tersebut jauh dibawah standar yang digunakan yaitu 5,5-7,0 detik (Bhattacharyya, 1978). Kondisi ini memberikan informasi bahwa nilai periode oleng kapal Atadroe termasuk kecil, sehingga olengan cepat dan menyentak-nyentak. Hal ini akan berakibat buruk terhadap kenyamanan kerja anak buah kapal. Nilai periode oleng disajikan pada Tabel 4.

Nilai periode oleng sebuah kapal sangat tergantung dari tinggi nilai metacentre (GM) dan radius girasi (radius of gyration) dari kapal tersebut. Semakin besar GM dengan lebar kapal yang tetap, periode oleng akan semakin kecil, demikian sebaliknya, semakin kecil GM maka akan semakin besar nilai periode olengnya (Bhattacharyya, 1978). Distribusi muatan 4 memiliki nilai periode oleng lebih kecil dibandingkan dengan lainnya, ini berarti waktu yang dibutuhkan kembali ke posisi semula lebih cepat dari kondisi muatan 5 (nilai periode oleng lebih besar). Hal ini mengindikasikan kedua penataan muatan berbeda, namun nilai periode oleng kelima distribusi muatan tidak berbeda 
jauh. Istopo (1997) menyatakan, nilai periode oleng pada distribusi muatan berbanding terbalik dengan initial GM.

Nilai periode oleng kecil (olengan cepat) memiliki keuntungan dan juga kerugian. Jika kapal mengalami kemasukan air atau perpindahan muatan atau air ballast yang besar, maka kapal akan lebih aman. Nilai periode oleng yang kecil akan mengakibatkan tegangan yang besar sehingga kapal akan menjadi kaku (stiff) dan menyentak-nyentak, sehingga akan menimbulkan kekurangnyamanan bagi awak ka- pal. Nilai periode oleng dapat diperbesar dengan memperkecil tinggi metacentre (GM) dengan cara menaikkan titik berat muatan.

Saat terjadi nilai periode oleng besar (olengan lambat) karena nilai GM kecil, maka hal sebaliknya akan terjadi, kapal akan menjadi langser (tender). Jika terjadi kemiringan besar, perpindahan muatan besar atau kebocoran, maka kapal akan menjadi relatif tidak aman. Nilai periode oleng besar akan mengakibatkan tegangan menjadi lebih kecil, sehingga kenyamanan awak kapal akan menjadi lebih baik.

Tabel 1 Hasil perhitungan perkiraan ton displacement ( $\Delta$ ), draft, KG, dan LCG

\begin{tabular}{ccccccc}
\hline No & \multicolumn{2}{c}{ Distribusi berat } & \multicolumn{3}{c}{ Nilai } \\
\hline & Muatan (\%) & BBM (\%) & $\mathbf{d}(\mathbf{m})$ & $\boldsymbol{\Delta}($ ton $)$ & KG $(\mathbf{m})$ & LCG $(\mathbf{m})$ \\
\hline 1 & 0 & 100 & 0,939 & 39,748 & 1,226 & $-0,523$ \\
2 & 100 & 20 & 1,006 & 44,321 & 1,158 & 0,004 \\
3 & 70 & 25 & 0,952 & 40,647 & 1,112 & 0,047 \\
4 & 50 & 20 & 0,914 & 38,073 & 1,119 & 0,113 \\
5 & 100 & 55 & 1,039 & 46,600 & 1,221 & $-0,304$ \\
\hline
\end{tabular}

Tabel 2 Luas area di bawah kurva stabilitas statis kondisi distribusi muatan

\begin{tabular}{ccccccc}
\hline \multirow{2}{*}{ Kriteria } & IMO Code & \multicolumn{5}{c}{ Kondisi distribusi berat } \\
\cline { 3 - 6 } & & 1 & 2 & 3 & 4 & 5 \\
\hline A & $0,055 \mathrm{~m} . \mathrm{rad}$ & 0,166 & 0,166 & 0,181 & 0,182 & 0,160 \\
B & $0,090 \mathrm{~m} . \mathrm{rad}$ & 0,263 & 0,262 & 0,288 & 0,291 & 0,251 \\
C & $0,030 \mathrm{~m} . \mathrm{rad}$ & 0,106 & 0,105 & 0,118 & 0,119 & 0,099 \\
D & $0,20 \mathrm{~m}$ & 0,56 & 0,55 & 0,62 & 0,63 & 0,52 \\
E & $>25^{\circ}$ & $34^{\circ}$ & $35^{\circ}$ & $36^{\circ}$ & $37^{\circ}$ & $34^{\circ}$ \\
F & $\geq 0,15 \mathrm{~m}$ & 1,26 & 1,3 & 1,36 & 1,39 & 1,25 \\
\hline
\end{tabular}

Tabel 3 Margin luas area di bawah kurva stabilitas statis kondisi muatan (\%)

\begin{tabular}{ccccccc}
\hline \multirow{2}{*}{ Kriteria } & IMO Code & \multicolumn{5}{c}{ Margin (\%) kondisi distribusi berat } \\
\cline { 3 - 6 } & & 1 & 2 & 3 & 4 & 5 \\
\hline A & $0,055 \mathrm{~m} . \mathrm{rad}$ & 202,516 & 202,476 & 228,458 & 231,269 & 190,523 \\
B & $0,090 \mathrm{~m} . \mathrm{rad}$ & 192,462 & 190,947 & 220,025 & 223,396 & 178,447 \\
C & $0,030 \mathrm{~m} . \mathrm{rad}$ & 254,607 & 249,660 & 292,763 & 298,123 & 232,773 \\
D & $0,20 \mathrm{~m}$ & 179,2 & 175,3 & 209,75 & 214,25 & 162,25 \\
E & $>25^{\circ}$ & 36 & 40 & 44 & 48 & 36 \\
F & $\geq 0,15 \mathrm{~m}$ & 740 & 766,66 & 806,66 & 826,66 & 733,33 \\
\hline
\end{tabular}


Tabel 4 Draft, ton displacement, KG,GM dan periode oleng hasil perhitungan

\begin{tabular}{cccccccc}
\hline \multirow{2}{*}{$\begin{array}{c}\text { Kondisi } \\
\text { muatan }\end{array}$} & \multicolumn{2}{c}{ Distribusi Berat } & \multicolumn{5}{c}{ Nilai } \\
\cline { 2 - 8 } & Muatan (\%) & BBM & $\mathrm{d}(\mathrm{m})$ & $\Delta$ (ton) & KG (m) & GM (m) & T (det) \\
\hline 1. & 0 & 100 & 0,939 & 39,748 & 1,226 & 1,26 & 3,17 \\
2. & 100 & 20 & 1,006 & 44,321 & 1,158 & 1,30 & 3,12 \\
3. & 70 & 25 & 0,952 & 40,647 & 1,112 & 1,36 & 3,05 \\
4. & 50 & 20 & 0,914 & 38,073 & 1,119 & 1,39 & 3,02 \\
5. & 100 & 55 & 1,039 & 46,600 & 1,221 & 1,25 & 3,18 \\
\hline
\end{tabular}

Tabel 5 Distribusi berat, nilai draft rata-rata (d), KG, GM, LCG dan ton displacement KM. Atadroe

\begin{tabular}{cccccccc}
\hline & \multicolumn{5}{c}{ Distribusi berat } & \multicolumn{5}{c}{ Nilai } \\
\cline { 2 - 7 } & Muatan (\%) & BBM & $\mathrm{d}(\mathrm{m})$ & $\Delta($ ton $)$ & KG $(\mathrm{m})$ & GM $(\mathrm{m})$ & LCG $(\mathrm{m})$ \\
\hline 1. & 0 & 100 & 0,94 & 39,748 & 1,23 & 1,26 & $-0,441$ \\
2. & 100 & 20 & 1,01 & 44,321 & 1,16 & 1,30 & 0,004 \\
3. & 70 & 25 & 0,95 & 40,647 & 1,11 & 1,36 & 0,047 \\
4. & 50 & 20 & 0,91 & 38,073 & 1,12 & 1,39 & 0,113 \\
5. & 100 & 55 & 1,04 & 46,600 & 1,22 & 1,25 & $-0,304$ \\
\hline
\end{tabular}

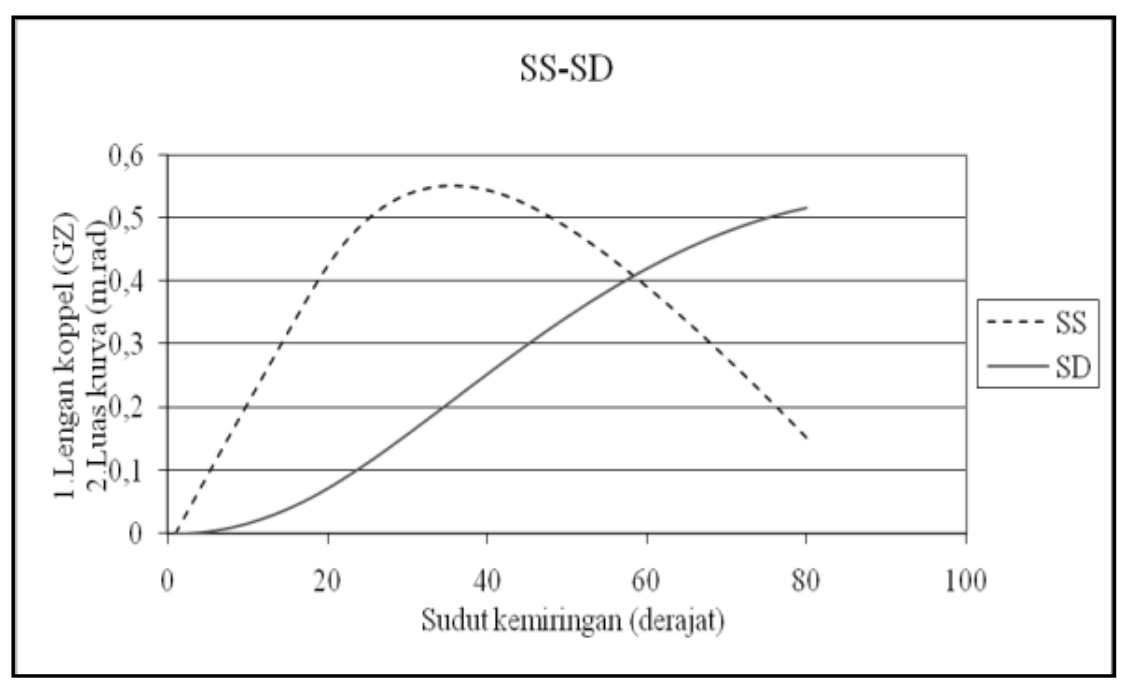

Gambar 6 Kurva stabilitas statis dan dinamis muatan 1 


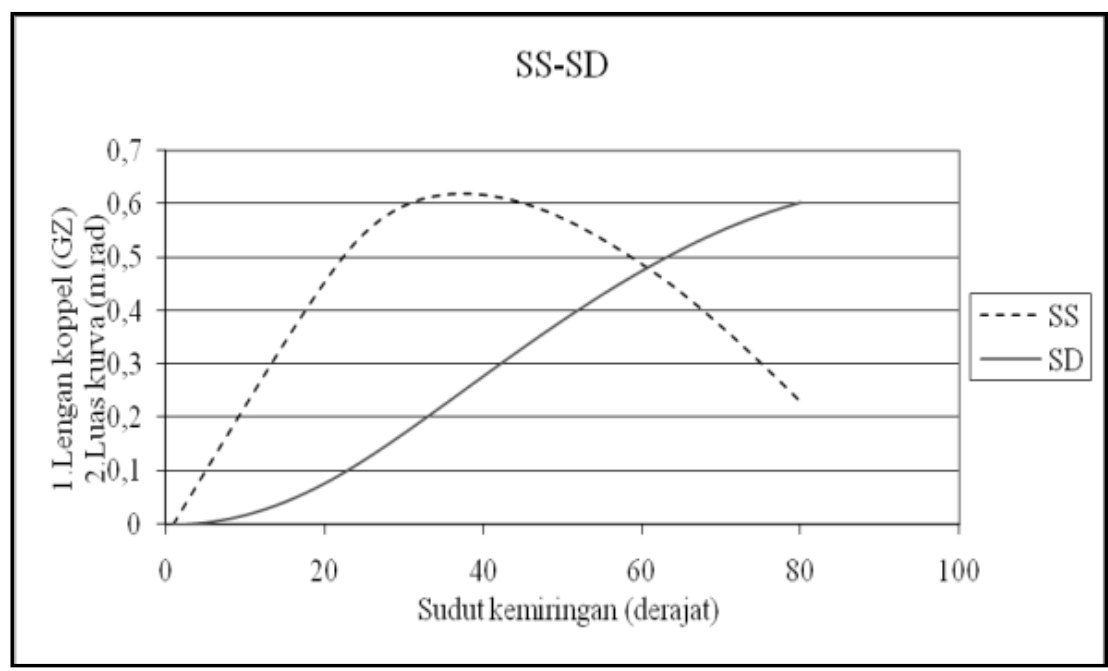

Gambar 7 Kurva stabilitas statis dan dinamis muatan 2

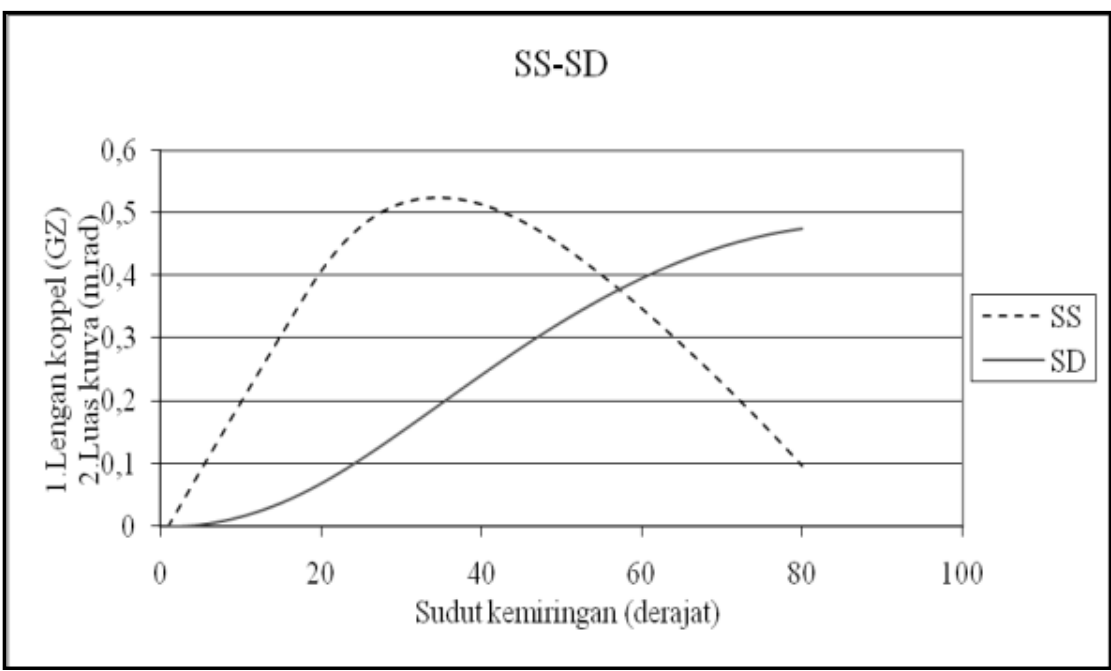

Gambar 8 Kurva stabilitas statis dan dinamis muatan 3

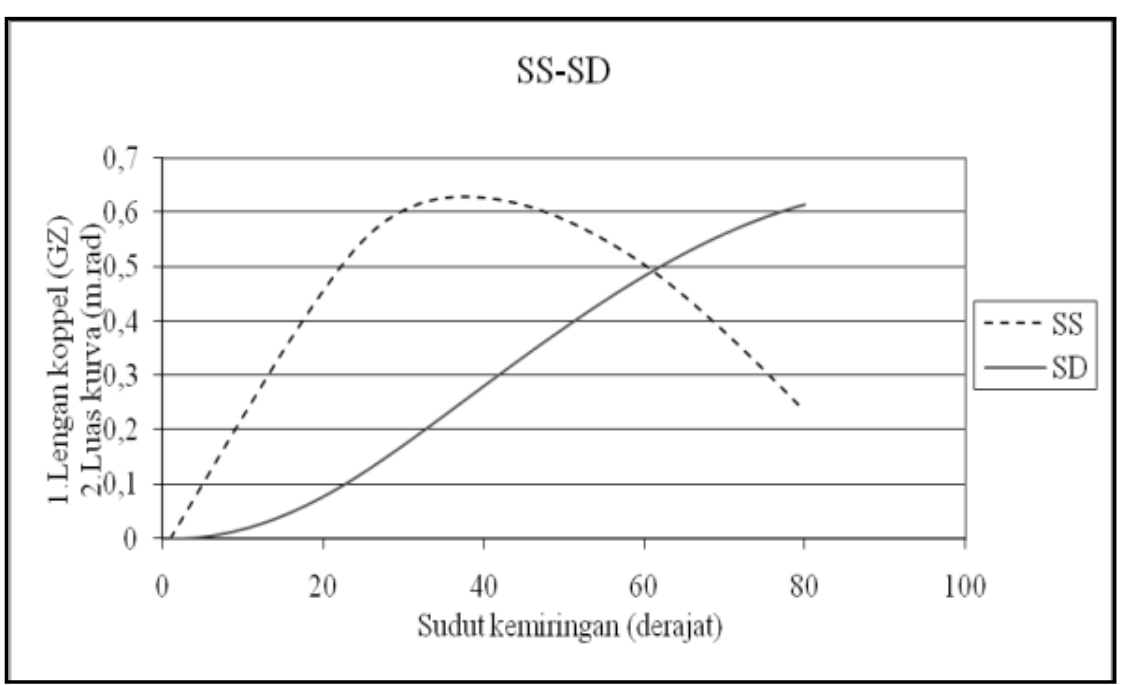

Gambar 9 Kurva stabilitas statis dan dinamis muatan 4 


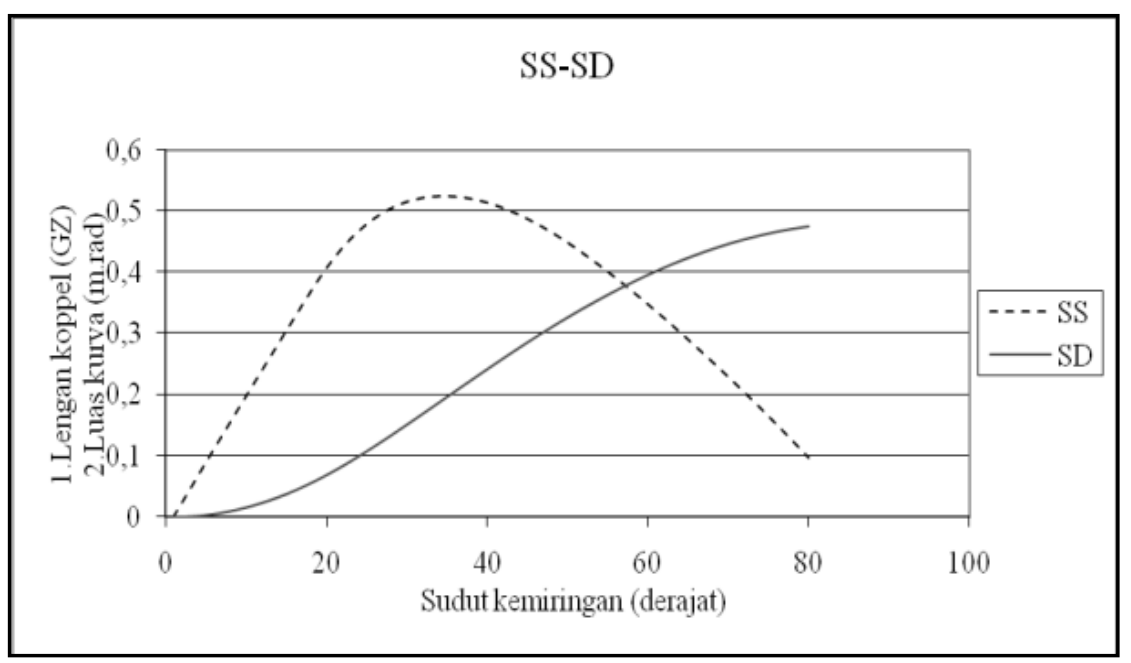

Gambar 10 Kurva stabilitas statis dan dinamis muatan 5

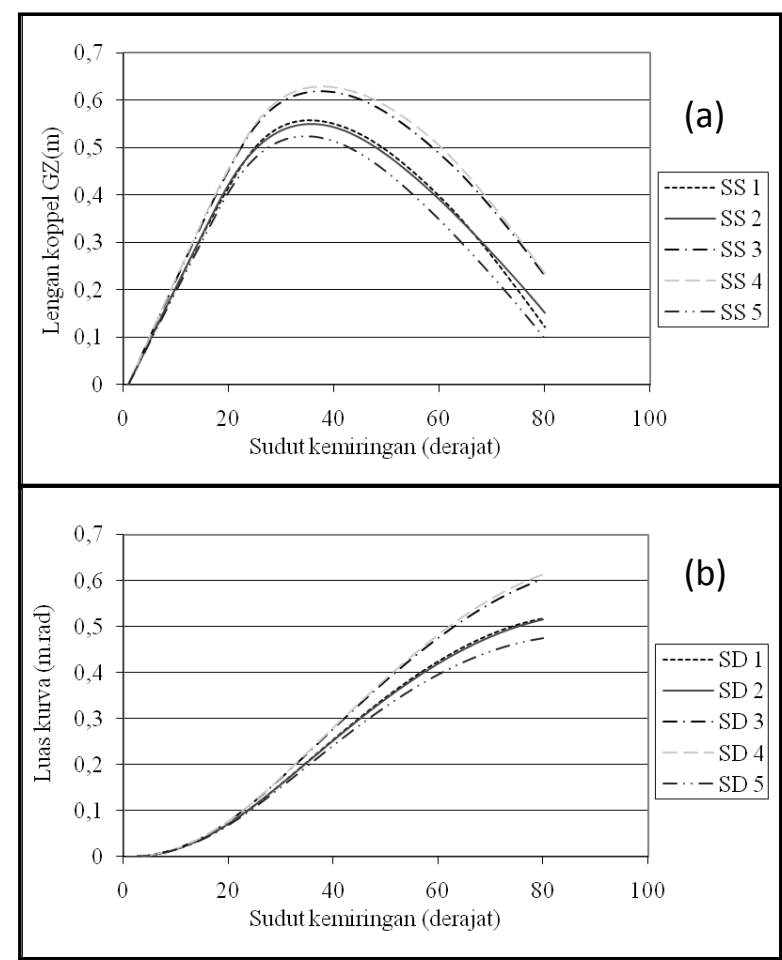

Gambar 11 Kurva stabilitas statis (a) dan dinamis (b).

\section{KESIMPULAN DAN SARAN}

\section{Kesimpulan}

Nilai KG kapal purse seine yang diteliti mengalami perubahan pada tiap perubahan muatan. Nilai KG terbesar pada kondisi muatan 1 (100\% BBM - 0\% muatan), dan KG terkecil pada kondisi muatan 3 (BBM tersisa $26 \%$ dan muatan $70 \%$ ).

Kelima variasi kondisi distribusi muatan menunjukkan stabilitas statis dan dinamis kapal baik, hal ini ditunjukkan nilai lengan penegak/ kopel (GZ) positif dan jauh di atas nilai minimum rekomendasikan IMO.

Nilai periode oleng kapal kecil, sehingga gerakan untuk kembali ke posisi semula (tegak) menjadi cepat dan menyentak-nyentak. Kondisi ini mengakibatkan tidak nyaman bagi awak kapal.

\section{Saran}

Konsentrasi muatan sebaiknya ditinggikan dari base line untuk memperbesar nilai periode oleng. 
Penambahan muatan masih memungkinkan untuk dilakukan, penambahan tersebut sebaiknya ditempatkan di atas deck pada lambung kiri, sehingga KG menjadi lebih tinggi.

Sebaiknya lebar (B) kapal diperbesar pada pembangunan kapal selanjutnya, sehing-ga oleng lebih lambat.

\section{DAFTAR PUSTAKA}

Bhattacharya R. 1978. Dynamic of Marine Vehicles. New York: John Wiley and Son, Inc.

[BBPPI]. Balai Besar Pengembangan Penangkapan Ikan Semarang. 2006. Pengertian Dasar Besaran-Besaran Kapal. Jakarta: Departemen Kelautan dan Perikanan.

Derrett DR. 1984. Ship Stability For Masters and Mater. "Ed ke- 4". England: Butler and Tenner Ltd.

Husni E. 2003. Analisis Gerakan Coupled Heaving-Pitching Kapal Purse Seine
Terhadap Gelombang Regular Head Seas [terhubung berkala]. http://www.tumoutu. Net/702.07134/edi husni.htm. [2 Mei 2009].

[IMO] International Maritime Organization. 1995. Code on Intact Stability For All Type of Ships Covered by IMO Instruments Resolution A. 749 (18).

Iskandar BH. 2007. Stabilitas Statis dan Dinamis Kapal Latih Stella Maris. Buletin PSP. No. 16(1): 31-49.

Istopo. 1997. Stabilitas Kapal. Jakarta: Yayasan Corps Alumni Akademi IImu Pelayaran (CAAIP).

Palumian. 1999. Stabiliteit. Jakarta: Yayasan Pendidikan Pelayaran Djadajat-1963.

Rawson KJ, and Tupper EC. 1983. Basic Ship Theory. "Ed ke-3". Volume 1. London: Longman. 